\title{
The Perceived Effectiveness of the Officer Certification Requirement under Sarbanes-Oxley
}

\author{
T. J. Engebretson \\ Heidi H. Meier \\ Cleveland State University, h.meier@csuohio.edu
}

Follow this and additional works at: https://engagedscholarship.csuohio.edu/bus_facpub

Part of the Accounting Commons

How does access to this work benefit you? Let us know!

Publisher's Statement

This is the accepted version of the following article: Engebretson, T. J., Meier, H. (2011). "The Perceived Effectiveness of the Officer Certification Requirement under Sarbanes-Oxley".

International Journal of Auditing, 15, pp. 176-190., which has been published in final form at http://onlinelibrary.wiley.com/doi/10.1111/j.1099-1123.2011.00428.x/abstract

\section{Original Published Citation}

Engebretson, T. J., Meier, H. (2011). "The Perceived Effectiveness of the Officer Certification Requirement under Sarbanes-Oxley". International Journal of Auditing, 15, pp. 176-190.

This Article is brought to you for free and open access by the Monte Ahuja College of Business at EngagedScholarship@CSU. It has been accepted for inclusion in Business Faculty Publications by an authorized administrator of EngagedScholarship@CSU. For more information, please contact library.es@csuohio.edu. 


\title{
The Perceived Effectiveness of the Officer Certification Requirement under Sarbanes-Oxley
}

\author{
T. Jean Engebretson ${ }^{1}$ and Heidi Hylton Meier $^{2}$ \\ 'Fairmont State University \\ ${ }^{2}$ Cleveland State University
}

The Sarbanes-Oxley Act of 2002 brought about sweeping changes that were meant to improve corporate reporting in the United States and to restore investor confidence following some of the largest business failures in US history. This study examines one requirement of this legislation, the certification of the financial statements by the Chief Executive Officer (CEO) and the Chief Financial Officer (CFO) by surveying stakeholder constituent groups to determine whether this new requirement is effective in accomplishing the goals established by Congress and the Securities and Exchange Commission (SEC). This is accomplished by using Cameron's strategic constituencies model to test seven research questions developed from the current literature which provides various points of view regarding the appropriateness of the $\mathrm{CEO} / \mathrm{CFO}$ certification. Based on the results of these tests, we see that there are significant differences among the perceptions of the constituent groups as to the effectiveness of this requirement.

Key words: Accounting, Sarbanes-Oxley Act, Section 302, CEO certification, CFO certification, audit, internal control, investor confidence, audit quality, corporate governance

\section{SUMMARY}

A major goal of the Sarbanes-Oxley Act of 2002 was to improve corporate reporting in the United States so as to restore investor confidence and stabilize the credit markets following major business failures in the US. One of the requirements of this law was to make officers more accountable through the certification of the financial statements by the

Correspondence to: Heidi Hylton Meier, Professor of Accounting, Department of Accounting, Cleveland State University, 1860 East 18th Street, Cleveland, Ohio, USA. Email: h.meier@csuohio.edu
Chief Executive Officer (CEO) and the Chief Financial Officer (CFO). Although the literature provided some discussion of this new requirement, there had been very little empirical evidence regarding the effectiveness of this new rule. This study attempts to fill that void and examines the effectiveness of this requirement by using a questionnaire to survey stakeholder groups (accounting educators, certified public accountants, internal auditors, bankers, and certified financial analysts) to determine how well each of these groups felt that this requirement would be in improving the quality of corporate reporting. 
After a thorough examination of the current literature and Section 302 of the Sarbanes-Oxley Act, seven research questions were developed and were tested using Cameron's strategic constituencies model in which we determined whether there were any differences among the perceptions of the constituent groups as to the effectiveness of this requirement. In conclusion, bankers differed with the other constituent groups in that they were more negative on most of their views, especially concerning the purpose of the requirement and specifically, that they have little confidence that the certification requirement will improve corporate reporting. In contrast, accounting educators were much more positive in their views, and in general believe that people and society can be changed through laws and regulation.

\section{INTRODUCTION}

As a result of one of the most notorious fraud schemes in recent memory, Enron Corporation filed for bankruptcy in early December 2001. Not surprisingly, the corporation's collapse was followed by several years of Congressional investigation and legal prosecution. During one such investigation, Jeffrey Skilling, a past Enron CEO, testified before the House Energy and Commerce Committee. During this testimony, $\mathrm{Mr}$ Skilling stated that he was unaware of any accounting practices designed to hide debt or make the company look more solvent than it really was' ('Lay may testify', 2002). Naturally, it is difficult to believe that the CEO of a major corporation could be that clueless about the operation of his own company; so unknowing, in fact, that 'others' could have perpetrated one of the largest contemporary fraud schemes right under his very nose while he remained completely unaware of it.

While it is not surprising that an individual accused of fraud or embezzlement would be less than forthcoming regarding their culpability in a fraud scheme, it is remarkable that so many of these individuals ultimately choose to blame the accountant while also claiming that they are unwitting victims themselves. Even though the 'I-am-not-an-accountant-so-I-am-not-responsible' defense may not be particularly credible, it has been specifically addressed in the reforms set forth in the Sarbanes-Oxley Act of 2002. The Act requires the CEO and CFO to certify that financial results are not false or misleading. Specifically, the principal executive and financial officers must 'certify' each annual and quarterly report that is filed under the Act that:

1. They have reviewed the report;

2. The report does not contain any material false statements or any material omissions of fact that would make it misleading, given their personal knowledge of the report; and

3. The financial information included in the report presents fairly, in all material respects, the financial position and results of operations of the company, given their personal knowledge of the company's performance. (Sarbanes-Oxley Act of 2002, Section 302, p. 37)

In addition to the report certification, the officers must also attest to the condition of the system of internal controls. Specifically, the CEO and CFO must assert that:

1. It is their responsibility to design and maintain the internal control system so that it will generate important information that will be communicated to the appropriate corporate officer for action;

2. They have evaluated said internal control system for effectiveness within 90 days of the financial report; and

3. They have issued a report regarding their conclusions concerning the effectiveness of the internal control system. The report must also include any significant changes to that system after the evaluation was made. (Sarbanes-Oxley Act of 2002, Section 302, p. 37)

Finally, the CEO and CFO must certify that they have disclosed to the auditor and the audit committee of the board of directors all significant deficiencies and material weaknesses in the internal control structure and any fraud cases involving employees who are key components in the internal control system (Sarbanes-Oxley Act of 2002, Section 302, p. 37).

\section{LITERATURE REVIEW}

There has been a considerable amount published about the Sarbanes-Oxley Act. Some authors have discussed the reasons for the legislation (Rezaee, 2005) and others have provided practical advice on the implementation of the law. Several authors have raised questions regarding whether new laws and regulations can achieve what prior laws and 
regulations could not (Ronen \& Berman, 2004; Romano, 2005). While many of these authors are quite skeptical (Ribstein, 2002; Heeren \& Rieckers, 2003) about how successful Sarbanes-Oxley will be in addressing the issues that Congress had hoped to resolve, some are optimistic that the financial reporting process will be improved (Geiger \& Taylor, 2003; Klein, 2003).

Although there has been much written about the Sarbanes-Oxley Act, most of this work has been presented without empirical results. However, there are a few research studies to note. Kinney et al. (2004) conducted a study regarding the services that are prohibited by the Act. The authors contended that there was no empirical justification by Congress or the SEC to prove that such services impair audit quality and they provide empirical evidence on 289 firms that restated their financial statements to determine any effects of providing non-audit services. They concluded that prohibiting financial services design but allowing tax services may improve the quality of financial reporting.

Nagy and Cenker (2007) surveyed Chief Audit Executives from 17 publicly held Northeast Ohio companies to determine the effect of Section 404 compliance on the internal audit profession. Their results showed that short-term benefits include improved job security, increased compensation, and greater visibility within the organization. However, the authors question whether these short-run benefits will have long-term costs by turning these departments into compliance units that require less professional judgment and expertise, concluding that perhaps organizations should form compliance groups to handle these new requirements so that internal auditors can resume their activities that add value and improve their organization's operations. Bryan (2009) and Bryan et al. (2008) interviewed high ranking corporate managers and analyzed their team approach to comply with Section 404 requirements of Sarbanes-Oxley and noted differences in their approaches.

The results of the current study, while exploratory in nature, provide additional empirical evidence regarding the effectiveness of SarbanesOxley by examining one part of the law, the certifications that are required by the CEOs and CFOs. By seeking the views of several different stakeholders, we attempt to determine whether this additional measure is perceived to enhance the reporting process.

\section{RESEARCH STUDY}

As a corporate governance mechanism, it appears that the purpose of the CEO certification requirement is to make corporate officers personally responsible for the financial information that is disseminated about their company. Gone are the days when the corporate officer can disavow any knowledge of wrongdoing and blame it solely on the accountant. Now, officers are required to be knowledgeable about internal control procedures and material weaknesses as well as accounting principles and professional codes of conduct.

Much has been written in the financial press concerning the advantages and disadvantages of the certification requirement. Some authors state that the requirement was necessary in order to give investors the requisite level of comfort to invest in the market after the collapse of Enron (Marden et al., 2003; Fornelli, 2007). Others believe that it will help corporations become more control conscious as well as aiding in the risk identification process (McConnell \& Banks, 2003; Henry, 2007). On the other hand, the process involved with certification will be arduous and time consuming and it is quite possible that the cost of the certification could outweigh its benefits (McConnell \& Banks, 2003; Grady, 2007; Scannell, 2007; Wilcox, 2007). Even if executive officers manage to complete the procedures necessary for certification, it may be impossible for them to attest to the information required by the Act. The officer may be incapable of actually knowing that there are no improprieties at some distant operations (Avellanet, 2003).

It seems that there are various points of view regarding the appropriateness of the CEO/CFO certification requirement to improve corporate governance in US companies. To measure effectiveness, a study based on a survey of the Act's constituents was conducted to determine the level of agreement on the following set of research questions which were derived from a review of prior literature:

RQ1: The constituent groups will agree that the $\mathrm{CEO} / \mathrm{CFO}$ certification requirement gives investors a greater sense of comfort following the Enron collapse.

RQ2: The constituent groups will agree that the $\mathrm{CEO} / \mathrm{CFO}$ certification requirement helps corporations become better at identifying risks and controlling operations. 
RQ3: The constituent groups will agree that the $\mathrm{CEO} / \mathrm{CFO}$ certification requirement will ensure that no false or misleading financial statements will be issued by corporations.

RQ4: The constituent groups will agree that the CEO/CFO certification requirement was unnecessary because the same statements are made to the auditor in the management representation letter.

RQ5: The constituent groups will agree that the costs of the CEO/CFO certification requirement will outweigh its benefits.

RQ6: The constituent groups will agree that the CEOs and CFOs cannot know what is happening at all their operations, especially in large, multinational companies.

RQ7: The constituent groups will agree that the $\mathrm{CEO} / \mathrm{CFO}$ certification requirement will induce CEOs and CFOs to create new methods to shield their personal assets from potential liability.

The following discussion provides an overview of how the literature was used in the development of these research questions. The first research question was derived based on the premise that there is some sentiment that the Act was solely a political gesture to make investors feel better (Marden et al., 2003). Therefore, this question is used to determine whether or not the CEO/CFO certification indeed gives investors a greater sense of comfort after the Enron disaster. The second question is based on the belief that the officer certification requirement will, in fact, help publicly traded corporations identify risks and become more control conscious (McConnell \& Banks, 2003). Most importantly, from the Act itself, it is stated that the overall purpose is to improve the transparency and accuracy of corporate reporting. Hence, in RQ3, the query is whether the CEO/CFO certification requirement would ensure that the financial report was accurate.

Some authors stated that the $\mathrm{CEO} / \mathrm{CFO}$ certification was unnecessary due to the assertions already made in the representation letter (Marden et al., 2003) or due to its excessive cost in both time and money (McConnell \& Banks, 2003). The fourth research question was based on these studies as was RQ5, focusing on the cost of certification and whether it would outweigh its benefits given the time-consuming effort required to generate it.
Finally, the last two research questions dealt with the more pragmatic issues of the certification requirement. Some authors have stated that it will be impossible to be certain that the information generated in distant locations is accurate (Avellanet, 2003). Therefore, the sixth research question asks if it is even possible for the CEO/ CFO to know if the information is accurate, especially the information generated at distant operations. The last question, RQ7, concerns the all too human desire of officers to protect themselves. The certification requirement makes executives personally liable for false information included in the report. As a result, officers may need to devise methods that can be used to shield their personal assets in the event malfeasance is discovered in the report (Marden et al., 2003) and this question focuses on the effect the certification requirement will have on a company's officials.

\section{Measuring effectiveness}

There are several models available to measure effectiveness. However, each one struggles with the problem of defining 'effectiveness' as 'effective' means different things to different people at different times. Researchers always want to develop a comprehensive list of indicators or predictors that can be applied to any situation to measure the effectiveness of an organization or system. It is possible that attempting to create such a comprehensive list of effectiveness predictors is a futile endeavor. According to Cameron, 'consensus regarding the best, or sufficient, set of indicators of effectiveness is impossible to obtain. Criteria are based on the values and preferences of individuals and no specifiable construct boundaries exist (Cameron, 1986, p. 541). A model specifically based on this notion that each individual measures effectiveness differently is known as the strategic constituencies model. In this model, effectiveness is determined by how well 'all strategic constituencies are at least minimally satisfied' (Cameron, 1986, p. 542). There are several variations of this model (e.g., relativism, power, social justice, evolutionary, etc.). Yet, each variation of the model has a core component that states effectiveness is evaluated by how well the interests of various constituencies have been satisfied. Any individual or groups of individuals with a stake in the organization or system is considered to be a constituent of the system (Gibson et al., 1997). 
This model has been useful in evaluating effectiveness in those cases where there are few concrete or measurable goals, objectives, or outputs (see Alam et al., 2000; Engebretson, 2006).

The social test [is] to be the most suitable for those units that cannot be measured with absolute empirical standards due to ... the lack of clear measurable outputs. The effectiveness of these units can be assessed meaningfully only by the opinion of some referent groups. (Tsui, 1990, p. 459)

Consequently, the constituencies model seems especially appropriate for measuring the effectiveness of the Sarbanes-Oxley Act and its components. The Act is a broad legislative measure with a stated purpose of improving audit quality, financial reporting quality, and corporate governance procedures. As such, it has impacted many diverse groups in the financial reporting process including investors, creditors, certified public accountants (CPAs), public accounting firms, audit committees, managers, officers, and directors of publicly traded companies. One can assume that each different constituency will have been impacted differently by the Act. If so, then each constituent group would view the effectiveness of the Act differently based on the personal experience of the constituents with the provisions of the Act and the execution of those provisions.

A key postulate of the multiple constituency model is that the organization is usually not able to satisfy the interests of different constituencies simultaneously.... In other words, the predictors of effectiveness, strategic or environmental, may vary with different constituencies. (Tsui, 1989, p. 188)

If each different constituent group can be expected to have a different opinion of the effectiveness of the certification requirement, the agreement of different constituencies on the evaluation of the effectiveness of the certification requirement would provide some support for the effectiveness of the certification requirement in improving corporate governance procedures in the US.

It should be noted, however, that this study will only assess one measurement of the effectiveness construct. It is not, nor does it purport to be, the only or even the best measure of effectiveness. In fact, one of the best measurements of the effectiveness of the Act would be to compare the number of fraudulent financial statements published before the passage of the officer certification requirement to the number published after the requirement became enacted. Unfortunately, publicly traded companies do not advertise that they are publishing fraudulent financial statements. It is unlikely that any company would openly admit to such activity in a researcher's study. Misstatements can occur for years before they are detected by the financial community. As a result, a more direct measurement of effectiveness seems unavailable at this time and instead, this research study will use the multiple constituencies model to evaluate the effectiveness of the CEO/CFO certification requirement as expressed by the constituent groups impacted by the Act.

\section{Constituent groups defined}

This study will examine whether various stakeholder groups are in agreement regarding their belief about the effectiveness of the CEO/ $\mathrm{CFO}$ certification requirement to improve corporate governance. The results of the study will greatly depend upon the constituent groups that are identified and included in the research study.

The Sarbanes-Oxley Act is a sweeping reform package with stated designs on improving corporate reporting in the US. It is imperative to consider the views of public accountants and corporate management, who are the two constituent groups most affected by this legislation. In addition, the Act has a stated goal of protecting the investing public, and therefore, users of financial statements are also included in the study. Consequently, the constituent groups to be included in the study are accountants, corporate management, and financial statement users.

\section{Instrument design}

The research instrument is a survey that was developed through an examination of the Sarbanes-Oxley Act, audit quality literature, and critiques of the Act in the financial press. In addition to the seven research questions that were previously discussed, standard demographic data were requested from each participant as well as an evaluation of their level of knowledge about the Act. For purposes of control, a respondent was asked to rate his or her familiarity with the Act. As the results of the survey would be meaningless if 
Table 1: Response rate

\begin{tabular}{lcccccc}
\hline & Bankers & CFAs & CPAs & Educators & $\begin{array}{c}\text { Internal } \\
\text { anditors }\end{array}$ & Total \\
\hline Total responses & 53 & 48 & 65 & 66 & 90 & 322 \\
Less: unusable responses & $(2)$ & $(1)$ & $(5)$ & $(4)$ & $(2)$ & $(14)$ \\
Usable responses & 51 & 47 & 60 & 62 & 88 & 308 \\
Final response rate & $17.59 \%$ & $13.78 \%$ & $21.13 \%$ & $21.38 \%$ & $30.34 \%$ & $20.60 \%$ \\
\hline
\end{tabular}

the respondent has no knowledge of the Act, those surveys were excluded from the data analysis if the participant stated that he or she was unfamiliar with the Act.

As the survey questions used in this paper were developed expressly for this research study, the validity of the survey questions to actually measure the construct under study was first established. The survey questions were first evaluated for content by CPA practitioners. The results of this pre-test were used to revise, format, and condense the survey instrument. A pilot study of the formatted questionnaire was then conducted of CPA practitioners, bankers, and internal auditors. Revisions to the survey instrument were again made as a result of the feedback from the pilot study.

\section{Survey implementation and response rate}

The constituent groups to be included in the study are accountants, corporate management, and financial statement users. The accountant constituent group was represented by CPAs and accounting educators. The financial statement user constituent group was represented by chartered financial analysts (CFAs) representing the investor category of financial statement users and bankers representing creditors. Finally, the corporate management group was represented by internal auditors.

A total of 1,600 surveys were administered by mail to the stakeholder groups listed above. Steps were taken to improve the response rate of the survey including a personalized cover letter, a reminder postcard, and a second request mailing. In addition, the survey instrument itself was designed to appear short and easy to complete. A total of 63 surveys were marked 'return to sender' and 42 surveys were returned by individuals who no longer worked in the relevant profession, so the final survey consisted of a total of 1,495 potential research subjects.
The response for this survey is presented in Table 1. A total of 322 surveys were returned. Of those, 14 were not useful for data analysis, primarily due to missing data, resulting in a response rate of almost $21 \%$. In addition, a test for non-response bias was conducted on the survey data. The 308 usable responses from the survey were divided into two groups: early responders and late responders. The responses of the late responders are assumed to be similar to those of non-respondents for this survey (Armstrong \& Overton, 1977). A test of means was conducted on the variables from the survey questions of relevance to this paper to determine any significant differences in the means of the two groups. No significant differences were found in any of the variables and, consequently, this would suggest that there is not a significant level of non-response bias in the sample.

\section{RESULTS}

\section{Demographics}

Demographic data was requested of each respondent, including age, gender, education level, professional credentials, profession, and years employed in the profession. The information for each constituent group appears in Table 2. Overall, nearly 80 percent (243) of the individuals responding to the survey were male and 76 percent (234) of the respondents were between the ages of 40 and 60 . Individually, it would appear that bankers and CFAs represent the youngest constituents (22 percent and 25 percent under 39 years old, respectively). Of the total respondents, approximately 40 percent (122) had a bachelor's degree and 41 percent (126) had a master's degree. Most of the survey participants have a CPA license (69 percent or 202 respondents).

Other information was requested regarding the respondent's employer characteristics. These included the employer's primary industry and total 
Table 2: Demographic information

\begin{tabular}{|c|c|c|c|c|c|}
\hline & $\begin{array}{c}\text { Bankers } \\
(n=51)\end{array}$ & $\begin{array}{c}\text { CFAs } \\
(n=47)\end{array}$ & $\begin{array}{c}\text { CPAs } \\
(n=60)\end{array}$ & $\begin{array}{c}\text { Educators } \\
\quad(n=62)\end{array}$ & $\begin{array}{c}\text { Internal } \\
\text { auditors } \\
(n=88)\end{array}$ \\
\hline \multicolumn{6}{|l|}{ Gender } \\
\hline Male & $39(76 \%)$ & $41(87 \%)$ & $47(78 \%)$ & $39(63 \%)$ & $77(88 \%)$ \\
\hline Female & $12(24 \%)$ & $6(13 \%)$ & $13(22 \%)$ & $23(37 \%)$ & $11(12 \%)$ \\
\hline \multicolumn{6}{|l|}{ Age } \\
\hline$<30$ yrs & $1(2 \%)$ & $3(6 \%)$ & $1(2 \%)$ & $3(5 \%)$ & $1(1 \%)$ \\
\hline $30-39$ yrs & $10(20 \%)$ & $9(19 \%)$ & $0(0 \%)$ & $5(8 \%)$ & $4(5 \%)$ \\
\hline $40-49$ yrs & $16(31 \%)$ & $15(32 \%)$ & $21(35 \%)$ & $18(29 \%)$ & $43(49 \%)$ \\
\hline $50-59$ yrs & $17(33 \%)$ & $12(26 \%)$ & $27(45 \%)$ & $27(44 \%)$ & $38(43 \%)$ \\
\hline$>60$ yrs & $7(14 \%)$ & $8(17 \%)$ & $11(18 \%)$ & $9(14 \%)$ & $2(2 \%)$ \\
\hline \multicolumn{6}{|l|}{ Education } \\
\hline Bachelor's & $34(66 \%)$ & $10(21 \%)$ & $37(62 \%)$ & $0(0 \%)$ & $41(47 \%)$ \\
\hline Master's & $10(20 \%)$ & $34(73 \%)$ & $20(33 \%)$ & $17(27 \%)$ & $45(51 \%)$ \\
\hline \multirow{2}{*}{\multicolumn{6}{|c|}{ Years in the profession }} \\
\hline & & & & & \\
\hline$<10$ yrs & $5(10 \%)$ & $10(21 \%)$ & $3(5 \%)$ & $18(29 \%)$ & $14(16 \%)$ \\
\hline $10-20$ yrs & $15(29 \%)$ & $17(36 \%)$ & $12(20 \%)$ & $25(40 \%)$ & $38(43 \%)$ \\
\hline $21-30$ yrs & $21(41 \%)$ & $12(26 \%)$ & $27(45 \%)$ & $13(21 \%)$ & $29(33 \%)$ \\
\hline$>30$ yrs & $10(20 \%)$ & $8(17 \%)$ & $18(30 \%)$ & $6(10 \%)$ & $7(8 \%)$ \\
\hline
\end{tabular}

number of people employed. The primary industries reported by participants included colleges/universities (19 percent), banking (19 percent), public accounting (18 percent), and financial services consulting (14 percent). Most of the employers were either small businesses with less than 100 employees (34 percent) or large employers with more than 1,000 employees (31 percent).

\section{Pro-certification questions}

Three questions in the survey instrument were investigating the perceptions of the more positive aspects of the CEO/CFO certification requirement. Specifically, the survey asked participants if the requirement would give investors a greater sense of comfort following the Enron collapse, if it would improve the entity's risk identification process and control consciousness, and if the requirement would ensure that the report does not contain any material untrue statement or omission of fact. Responses were recorded on a five-point Likert-type scale $(1=$ Strongly agree, $5=$ Strongly disagree).

Results were evaluated using the one-way or single factor analysis of variance (ANOVA) for the responses for each of the research questions. ANOVA is a commonly used procedure for testing the equality of the means for more than two populations. The equality of means was tested by comparing two estimates of the variance common to the separate populations (variance between the samples and variance within the samples) (Triola, 2007). It is an appropriate statistical test for this type of analysis because it: (i) examines differences in the sample average for more than one group; (ii) does not require the samples to be of equal size; and (iii) uses samples that are simple random samples that are independent of one another and are categorized in only one way (Triola, 2007) (constituent groups).

Following the ANOVA, the calculation of a significant $F$-test was used to indicate if a statistical difference in the means exists. However, it does not identify which means are different, and in order to identify which groups have different means, additional testing is required. Although there are several methods available, the Scheffe test was chosen for this study. The Scheffe test is a post-hoc method for adjusting significance levels in ANOVA and is considered to be a 'conservative' test, tending to err on the side of underestimating significance (Vogt, 1993, p. 204). It is a test that is used often, is known to work well in cases with unequal cell sizes, and will provide specific information on which means are significantly different from each other. These results are presented in the discussion below. 
Research question 1: Investor comfort

Many critics of the Sarbanes-Oxley Act have stated that its sole purpose was to restore investor confidence in the market without any substantive improvements in the governance of corporations. One of the survey questions specifically asked if the $\mathrm{CEO}$ and CFO certification will give investors a greater sense of comfort following the Enron collapse. A univariate ANOVA was conducted by constituent groups. The ANOVA was significant with $F_{4,303}(0.05)=8.54, p<0.001$. Post-hoc analysis using the Scheffe Test revealed significant mean differences. Bankers had higher mean scores compared to internal auditors, CFAs, and accounting educators. In addition, CPAs had higher mean scores compared to educators. Lower scores indicate agreement with the statement that the certification requirement would give jittery investors a greater sense of comfort in unstable financial times. The means and standard deviations for RQ1 are presented in Table 3.
The first research question revealed that there were significant mean differences by the creditor and the accountant constituent groups. Bankers had significantly higher mean scores than internal auditors, CPAs, and educators. One possibility for these results is that bankers believe that the purpose of the legislation was not merely to coddle jittery investors and that the certification requirement will bolster the credibility and truthfulness of the financial statements that they use every day. Another possible explanation could indicate that bankers believe the purpose of the certification requirement was to calm investors but that it may not be completely effective in doing so.

Likewise, CPAs also had significantly higher mean scores than educators. While both groups were considered the accountant constituent, accountants in public practice and accountants in education have a very different perspective. Public practice involves the practical application of accounting pronouncements while accounting education can be more theoretical. It is not

\begin{tabular}{|c|c|c|c|c|c|}
\hline Research question & Bankers & CFAs & CPAs & Educators & $\begin{array}{l}\text { Internal } \\
\text { atiditors }\end{array}$ \\
\hline \multicolumn{6}{|c|}{ RQ1: Investor comfort } \\
\hline Means & 3.37 & 2.55 & 2.88 & 2.27 & 2.54 \\
\hline SD & 1.04 & 1.11 & 1.18 & 0.94 & 1.08 \\
\hline$n$ & 51.00 & 47.00 & 60.00 & 62.00 & 88.00 \\
\hline \multicolumn{6}{|c|}{ RQ2: Control consciousness } \\
\hline Means & 2.96 & 2.53 & 2.91 & 2.37 & 2.27 \\
\hline $\mathrm{SD}$ & 0.94 & 0.95 & 1.15 & 1.10 & 1.03 \\
\hline$n$ & 51.00 & 47.00 & 60.00 & 62.00 & 88.00 \\
\hline \multicolumn{6}{|c|}{ RQ3: Report accuracy } \\
\hline Means & 3.70 & 3.55 & 3.95 & 3.90 & 3.51 \\
\hline SD & 1.10 & 1.05 & 0.99 & 1.01 & 1.12 \\
\hline$n$ & 51.00 & 47.00 & 60.00 & 62.00 & 88.00 \\
\hline \multicolumn{6}{|c|}{ RQ4: Management representation letter } \\
\hline Means & 2.61 & 3.36 & 3.38 & 3.69 & 3.81 \\
\hline SD & 1.18 & 1.13 & 1.24 & 1.12 & 1.22 \\
\hline$n$ & 51.00 & 47.00 & 60.00 & 62.00 & 88.00 \\
\hline \multicolumn{6}{|l|}{ RQ5: Cost/benefit } \\
\hline Means & 2.34 & 3.04 & 3.31 & 3.50 & 3.44 \\
\hline $\mathrm{SD}$ & 1.04 & 1.19 & 1.15 & 1.18 & 1.11 \\
\hline$n$ & 50.00 & 46.00 & 60.00 & 62.00 & 88.00 \\
\hline \multicolumn{6}{|c|}{ RQ6: Unable to know } \\
\hline Means & 2.31 & 2.48 & 2.50 & 2.56 & 2.84 \\
\hline SD & 1.14 & 1.10 & 1.19 & 1.08 & 1.20 \\
\hline$n$ & 50.00 & 46.00 & 60.00 & 62.00 & 88.00 \\
\hline \multicolumn{6}{|c|}{ RQ7: Executive personal liability } \\
\hline Means & 1.86 & 1.89 & 2.25 & 2.43 & 2.20 \\
\hline $\mathrm{SD}$ & 0.80 & 0.66 & 0.86 & 0.93 & 0.86 \\
\hline$n$ & 50.00 & 47.00 & 60.00 & 62.00 & 88.00 \\
\hline
\end{tabular}


surprising that CPAs may be more skeptical of the effectiveness of the Act than were educators. As with the banking constituents, it is possible that CPAs believe that the Act's underlying purpose was more substantive than has been portrayed in the financial press. It is also possible that CPAs believe that the Act will give management the impetus to improve the quality and transparency of their corporate financial reporting. On the other hand, it could also indicate that CPAs believe that the purpose of the Act was, in fact, to soothe nervous investors but that this goal may not be achieved through the certification requirement. For both the banking and CPA constituent groups, further research needs to be conducted to determine the specific reasons for these constituent groups' dissatisfaction with the certification requirement.

\section{Research question 2: Control consciousness}

Proponents of the Act argue that through the process of implementing the provisions of the Act, corporations will become better at identifying risks. It would also make the corporations more internal control conscious. One question in the survey asked the constituent groups if the CEO/CFO certification would improve the entity's risk identification process and enhance control consciousness throughout the organization. A univariate ANOVA was conducted by constituent groups. The ANOVA was significant with $F_{4,303}(0.05)=5.80, p<0.001$. Post-hoc analysis using the Scheffe Test revealed significant mean differences. Bankers had higher mean scores than internal auditors and accounting educators. In addition, CPAs had higher mean scores than internal auditors. Lower mean scores indicate agreement with the statement that the Act will improve internal control consciousness and the risk identification process. The means and standard deviations for RQ2 are presented in Table 3.

The second research question concentrated on the idea that the Act would make the management of a corporation more control conscious. Management would become better at identifying the risks that threaten the existence and prosperity of the organization. In so doing, management could take the appropriate steps to mitigate or even eliminate some of these risks. However, RQ2 also revealed that bankers and CPAs once again had significantly different views from the other constituent groups. Bankers had significantly different mean scores than internal auditors and educators and CPAs had higher mean scores than internal auditors.

It appears that bankers are skeptical concerning the certification's impact on the company's risk analysis process. Perhaps the results are due to the nature of the banking industry, in that bankers use financial statements to evaluate the creditworthiness of a particular business. During the course of that credit evaluation, bankers, like management, also evaluate the potential risks that a company may face in order to determine the risk of insolvency by the potential debtor. Perhaps bankers have already concluded that some companies are very good at risk analysis while others are not; this risk analysis process is a part of everyday business activities in a global market. Consequently, the certification requirement, in regard to risk analysis and control consciousness, is either redundant or ineffective.

Furthermore, CPAs appear more skeptical than internal auditors. The results of this test may be a result of the level of independence that the external auditor has had as opposed to the internal auditor as they are still employees of the corporation. The external auditor has always had more leverage where the audit client is concerned, and now Sarbanes-Oxley finally gives internal auditors the ability to require that the company enforce the sound internal control procedures that the internal auditor has been 'suggesting' for decades. As such, it would not be surprising that internal auditors would value the Act's influence on risk analysis and control consciousness more than the external CPA would.

\section{Research question 3: Report accuracy}

The stated purpose of the Sarbanes-Oxley Act of 2002 is to promote the accuracy and transparency of financial reports in the US. Some argue that making executive officers personally responsible for the corporation's reports will improve the accuracy and transparency of such reports. To that end, one question in the survey asked constituent groups if the CEO and CFO certification will ensure that the report does not contain any untrue statement or material fact or any omission of material fact. A univariate ANOVA was conducted by constituent groups. The ANOVA was not significant with $F_{4,303}(0.05)=2.28, p<0.060$, and post-hoc tests revealed no significant mean differences between constituent groups. Higher 
mean scores indicate disagreement with the survey question. The means and standard deviations for RQ3 are presented in Table 3.

The third research question dealt with the ability of the Act to eliminate materially misstated financial statements. Participants were asked if the CEO/ $\mathrm{CFO}$ certification requirement would ensure that no materially misstated financial statements would be issued. RQ3 was not supported as all five constituent groups disagreed with the idea that the certification requirement would guarantee that the financial statements are accurate. It seems apparent in the results of the survey that all parties involved with the financial statements realize or expect some misstated financial statements to 'slip through the cracks.' Regulation of financial markets had been in place for decades, yet Enron and Worldcom still occurred. Mere legislation is unable to cure the human race of greed and as such, Enron-like cases will occur again in the future. In this case, more legislation is unlikely to succeed where past legislation has failed. Certain individuals will choose to take illegal actions in spite of the consequences. If criminal prosecution is not already a deterrent to illegal action, adding a certification requirement is unlikely to change the results. The results of this survey appear to support this argument.

\section{Anti-certification questions}

Four questions in the survey instrument investigated the more negative aspects of the executive officer certification requirement. Specifically, the questions asked if the requirement was unnecessary due to the management letter; if the costs outweigh the benefits; if the officers are incapable of knowing whether the information is accurate; and if the requirement will lead to various attempts by officers to shield personal assets from exposure to lawsuits. Responses were recorded on a five-point Likert-type scale $(1=$ Strongly agree, $5=$ Strongly disagree).

\section{Research question 4: Management representation letter}

Many critics of the Act felt that the provisions of the Act were unnecessary. It was already a crime to issue false financial statements, yet numerous fraudulent financial statements were issued anyway. As with the certification requirement, management already made these representations to the company's auditor making certification of the report unnecessary and redundant. One question in the survey asked constituent groups if certification is unnecessary because the officers already provide assurances to the auditor in the management representation letter. A univariate ANOVA was conducted by constituent groups. The ANOVA was significant with $F_{4,303}(0.05)=9.17$, $p<0.001$. Post-hoc analysis using the Scheffe Test revealed significant mean differences. Internal auditors, CFAs, CPAs, and educators all had higher mean scores than bankers. Lower mean scores indicate agreement with the statement that the management representation letter was sufficient. The means and standard deviations for RQ4 are presented in Table 3.

Respondents were asked if the certification requirement was unnecessary given the fact that management was already required to sign a representation letter for the external auditor. Such representation letters include statements that management has disclosed all information relevant to the audit of the financial statements to the auditor during the course of the audit. All constituent groups except bankers disagreed with the idea that the certification requirement was unnecessary because management has already signed the management representation letter to the auditor. Bankers appear to believe that the management representation letter is enough. This response is consistent with the results of the previous research question. In the previous results, bankers had less confidence in the Act's ability to restore confidence in the market, to help the risk analysis process, or to improve the accuracy of the financial statements. In this case, the results suggest that bankers believe that the certification requirement adds little additional credibility to the financial statements beyond what was already gained through the management representation letter. It does not necessarily indicate that bankers have any confidence in the management representation letter to the auditor. It just indicates that they are no more confident in the financial statements after the certification requirement than they were when management was just signing a representation letter for the auditor. In fact, it is entirely possible that bankers were dissatisfied with the system then and are still dissatisfied with the system now. The certification requirement has done little to increase their confidence in the financial reporting process. 


\section{Research question 5: Cost/benefit}

As many executive officers come from management or marketing positions, it is conceivable that they may not possess the requisite knowledge base to actually certify the reports as required by the Act. Training CEOs and CFOs in order that they may competently certify the report requires a significant amount of time and effort. Even if they are familiar with accounting control procedures in such depth to make the certification credible, it will still require an inordinate amount of time and effort to complete the work necessary in order to certify the financial reports. One question on the survey asked if the CEO/CFO certification will be arduous and time-consuming such that the costs will outweigh the benefits. A univariate ANOVA was conducted by constituent groups. The ANOVA was significant with $F_{i, 301}(0.05)=9.60, p<0.001$. Post-hoc analysis using the Scheffe Test revealed significant mean differences. Internal auditors, CPAs and accounting educators all had higher mean scores than bankers. Higher mean scores indicate disagreement with the statement that the costs will outweigh the benefits. The means and standard deviations for RQ5 are presented in Table 3.

Responses to RQ5 reveal significant mean differences between internal auditors, CPAs, educators, and bankers. The means of the other constituent groups are higher than that of bankers which suggests that bankers are more in agreement with the idea that the cost of the certification requirement exceeds the benefits. The other constituent groups appear to believe the benefits of the certification requirement are worth the cost. Once again, the results of this research question are consistent with the previous results. As bankers do not believe that the certification requirement adds much value concerning credibility of the financial statements or improvements in the internal governance mechanisms of the corporation, it stands to reason that the banking constituent group would also feel that the cost of implementation would necessarily exceed its benefit. On the other hand, it is also not surprising that internal auditors would feel that the cost was justified. As discussed previously, internal auditors gain a certain amount of enforcement leverage with their employer corporation that may have been absent prior to the passage of the Act. As such, the benefits to them far outweigh the costs of implementation. The interesting results for this research question, however, relate to educators. Educators really have no vested interest in the cost. They are not paying for it and they are not being paid for it. At least CPAs will reap the benefits of the increased costs which somewhat explains their response. Compliance costs related to the Act, especially in the first year, can be staggering. Now CPAs conduct an audit of the internal control system in addition to the financial statement audit. Such audits can create a whole new revenue stream for CPAs that did not exist prior to the Act. Educators, however, have no reason to believe that the cost is justified unless they really do believe that the certification requirement will improve the financial reporting process. That result would be consistent with the results of previous research questions in this paper. Educators appear inclined to believe that the certification requirement may help to calm nervous investors and improve the corporation's risk analysis procedures as well as to increase credibility of the financial reports beyond what was required solely by the auditor before the certification requirement existed. The results of this research question are consistent with this viewpoint for accounting educators.

\section{Research question 6: Unable to know}

In addition to the time-consuming nature of the work required for certification, there is some question as to whether it is even possible for executive officers to make this certification. This question on the survey asked constituent groups if CEOs and CFOs will be incapable of actually knowing that there are no improprieties at some distant operations. A univariate ANOVA was conducted by constituent groups. The ANOVA was not significant, with $F_{4,303}(0.05)=1.96, p<0.099$, and post-hoc tests revealed no significant mean differences between constituent groups. Lower mean scores indicate agreement with the statement in the survey instrument. The means and standard deviations for RQ6 are presented in Table 3.

RQ6 relates to the demanding nature of the certification requirement. Participants were asked if the financial officers would even be capable of knowing about control procedures in distant operations. All of the constituent groups agreed with lower mean scores. The results suggest that the parties involved with the Act recognize the inherent difficulties in the certification requirement. Based on those requirements, it may be impossible for the officers to do what is specified 
in the Act, even if they wanted to do it. It may be that the demands of the Act are too unreasonable. However, it is clearly apparent why the certification requirement was placed in the Act. All too many times we have seen corporate executives testify before Congress regarding areas of financial impropriety. Many of those testimonies blame the accountant. The CEO is just a figurehead with no knowledge of accounting rules and principles. The accountant should be held accountable for any impropriety in the financial statements. Yet, that defense is unacceptable. The massive cases of fraud that have occurred could not have taken place in the accounting department alone without the full knowledge of the financial officers. Congress wanted to force financial officers to take responsibility for the information that was being disseminated about the company. Consequently, the certification requirement is a reactionary and somewhat punitive measure. Participants acknowledge that it may be impossible for financial officers to actually know what the certification requirement demands, but they want them to try anyway. An executive that makes a good faith effort to understand and evaluate his or her own financial operations is far better than one who refuses to take any responsibility at all. It seems that the market participants are tired of the plausible deniability excuse and now want a proactive executive that takes his or her duty to the public very seriously.

\section{Research question 7: Executive personal liability}

The certification requirement makes the executive officers personally liable for the information that is reported. It is natural to assume that most executive officers will not want to expose their personal assets to the threat of shareholder lawsuits or federal prosecution. As such, these officers will be interested in developing methods to shield their personal assets from exposure. To accomplish this, Director's and Officer's (D\&O) insurance had commonly been used, but the industry had observed increases in D\&O insurance premiums by as much as 500 percent in 2002 (Isdale, 2005) and policy coverage was expected to be reduced. Therefore, additional methods had also been suggested, such as retitling assets, registering assets in a more favorable state, or the use of an asset protection trust (Isdale, 2005). Consequently, one question in the survey asked constituent groups if the certification will make executives personally responsible for their company's financial statements and will also create the desire for executives to shield their personal assets from shareholder lawsuits and federal prosecution. A univariate ANOVA was conducted by constituent groups. The ANOVA was significant with $F_{4,302}(0.05)=4.67$, $p<0.001$. Post-hoc analysis using the Scheffe Test revealed significant mean differences. Educators had higher mean scores than bankers or CFAs. Higher scores indicate disagreement with the sentiment that officers will attempt to shield their personal assets. The means and standard deviations are presented in Table 3 for RQ7.

$\mathrm{RQ7}$ deals with a very pragmatic issue. Do the constituents believe that corporate executives would try to shield their personal assets because the certification requirement would make them personally liable for the financial statements? Would shielding personal assets become more important than ensuring the financial statements were as accurate as possible? This research question was responded to with educators having significantly higher mean scores than bankers or CFAs. Once again, these results are consistent with the results of the previous research question. Educators have consistently demonstrated a belief in the value of the certification requirement.

The results of this study show that educators may believe that the certification requirement was necessary to restore confidence in the financial markets. Consequently, for this constituent group, the benefits of the legislation outweighed its cost. While it was clear that educators, like the other constituent groups, did not believe that this provision would completely eliminate fraudulent or materially misstated financial statements, they do seem to consistently view the provision in a more optimistic light, in general, as opposed to the banking constituent which consistently viewed the certification requirement more negatively. A summary of the results appears in Table 4.

\section{CONCLUSIONS}

This study looks at one small piece of the Sarbanes-Oxley Act of 2002, the CEO/CFO certification requirement. Five different constituent groups were asked several questions regarding the requirement. The degree of consensus among the groups was used as a means to determine if the requirement achieved its objective. The results indicate that all five groups were skeptical about the requirement's impact or ability to ensure accurate financial statements. All five constituent 


\begin{tabular}{|c|c|c|}
\hline RQ1 & $\begin{array}{l}\text { The constituent groups will agree that the CEO/CFO certification } \\
\text { requirement gives investors a greater sense of comfort following the } \\
\text { Enron collapse. }\end{array}$ & $\begin{array}{l}\text { Significant differences } \\
\text { among groups }\end{array}$ \\
\hline RQ2 & $\begin{array}{l}\text { The constituent groups will agree that the } \mathrm{CEO} / \mathrm{CFO} \text { certification } \\
\text { requirement helps corporations become better at identifying risks and } \\
\text { controlling operations. }\end{array}$ & $\begin{array}{l}\text { Significant differences } \\
\text { among groups }\end{array}$ \\
\hline RQ3 & $\begin{array}{l}\text { The constituent groups will agree that the CEO/CFO certification } \\
\text { requirement will ensure that no false or misleading financial statements } \\
\text { will be issued by corporations. }\end{array}$ & All disagreed \\
\hline $\mathrm{RQ4}$ & $\begin{array}{l}\text { The constituent groups will agree that the } \mathrm{CEO} / \mathrm{CFO} \text { certification } \\
\text { requirement was unnecessary because the same statements are made to } \\
\text { the auditor in the management representation letter. }\end{array}$ & $\begin{array}{l}\text { Significant differences } \\
\text { among groups }\end{array}$ \\
\hline RQ5 & $\begin{array}{l}\text { The constituent groups will agree that the cost of the CEO/CFO } \\
\text { certification requirement will outweigh its benefits. }\end{array}$ & $\begin{array}{l}\text { Significant differences } \\
\text { among groups }\end{array}$ \\
\hline RQ6 & $\begin{array}{l}\text { The constituent groups will agree that the CEOs and CFOs cannot know } \\
\text { what is happening at all their operations, especially in large, } \\
\text { multinational companies. }\end{array}$ & All agreed \\
\hline RQ7 & $\begin{array}{l}\text { The constituent groups will agree that the CEO/CFO certification } \\
\text { requirement will induce CEOs and CFOs to create new methods to } \\
\text { shield their personal assets from potential liability. }\end{array}$ & $\begin{array}{l}\text { Significant differences } \\
\text { among groups }\end{array}$ \\
\hline
\end{tabular}

groups also agreed that it was unlikely the CEOs and CFOs would have the necessary information from distant operations to even make a knowledgeable certification statement.

There were significant differences, however, in the other research questions. Bankers consistently differed from the other constituent groups concerning the purpose of the requirement, the risk assessment process, the necessity of the certification given the management representation letter, the costs relative to the benefits of the certification, and the personal liability issues of the officers. Their results are consistently negative across the research questions used in the study. It appears the bankers, as a constituent group, have little confidence in the certification requirement.

In addition, educators also differ significantly in their responses to several of the research questions. Their results are consistently more positive than some of the other constituent groups. This positive outlook may stem from the nature of their positions. Educators, in general, believe that people and society can be changed by training. Laws and regulations are a form of training where acceptable behavior is defined and unacceptable behavior is punished. As a result, it is not surprising that educators would view the Sarbanes-Oxley act in a more positive light.

Some limitations and additional observations also need to be mentioned. First of all, this study is based on survey research, and although every attempt was made during the execution and evaluation of results to minimize the potential for bias, such risk can never be totally eliminated. Secondly, this study was conducted before the current economic recession. It is possible, even probable, that results may be different in the current economic climate. It will be interesting to see whether professionals will still place value on this certification, or if it will even continue to be issued considering current court cases questioning the legality of Sarbanes-Oxley requirements ('Sarbanes-Oxley on Trial', 2009). And finally, the results concerning the banker constituent group are interesting. They are consistently more pessimistic than other financial statement users. It seems that creditors would be more pleased about CEOs and CFOs taking responsibility for the financial statements than appears in this study. Additional research is warranted to determine the specific cause of these results.

\section{ACKNOWLEDGMENTS}

The authors acknowledge and thank Professors Ravi Kamath, Pete Poznanski, and Raj Javalgi for their helpful comments and guidance, as well as the two anonymous reviewers and the editor, Professor Thomas McKee, for their suggestions and insights on the paper. 


\section{REFERENCES}

Alam, P., Hoffman, R. C. \& Meier, H. H. (2000), Perceptions of the peer review program of the accounting profession: implications for management', Journal of Managerial Isstues, Vol. 12, No. 4, pp. 408-27.

Armstrong, J. S. \& Overton, T. S. (1977), 'Estimating nonresponse bias in mail surveys', Journal of Marketing Research, Vol. 14, No. 3, pp. 396-402.

Avellanet, A. W. (2003), 'Is what-you-see really what-you-got?' Strategic Finance, Vol. 85, No. 3, pp. $1-3$.

Bryan, L. D. (2009), 'Corporate managers' experiences related to implementing Section 404 of the Sarbanes-Oxley Act: a focus on information systems issues', Journal of Applied Business Research, Vol. 25, No. 3, pp. 25-35.

Bryan, L. D., Yahr, M. A. \& Rota, D. R. (2008), 'Team-based approaches to compliance with Section 404 of the Sarbanes-Oxley Act', Joumal of Manngement and Marketing Research, Vol. 1, No. 1, 50-64.

Cameron, K. S. (1986), 'Effectiveness as paradox: consensus and conflict in conceptions of organizational effectiveness', Management Science, Vol. 32, No. 5, pp. 539-53.

Engebretson, T. J. (2006), "The Perceived Effectiveness of the Sarbanes-Oxley Act of 2002: A Multiple Constituency Approach', Doctoral Dissertation, Cleveland State University.

Fornelli, C. (2007), 'Investor confidence is easy to shake, hard to restore', Accounting Today, 21 May, pp. 6-7.

Geiger, M. A. \& Taylor, P. L., III (2003), 'CEO and CFO certifications of financial information', Accounting Horizons, Vol. 17, No. 4, pp. 357-68.

Gibson, J. L., Ivancevich, J. M. \& Donnelly, J. H., Jr. (1997), Organizations, Behnvior Structure Processes, 9th edn, Boston, MA: Irwin McGraw-Hill.

Grady, R. E. (2007), 'The Sarbox monster', The Wall Street Journal, 26 April, p. 19.

Heeren, K. A. \& Rieckers, O. (2003), 'Legislative responses in times of financial crisis - new deal securities legislation, Sarbanes-Oxley Act and their impact on future German and EU regulation', European Review of Private Law, Vol. 11, No. 5, pp. 595-628.

Henry, D. (2007), 'Not everyone hates Sarbox', Business Week, 29 January, p. 37.

Isdale, H. (2005), 'Directors: protect your personal assets: the more personal assets you have the greater your financial risk. What you can $\mathrm{do}^{\prime}$, Directors $\&$ Boards, 1 January.

Kinney, W. R., Jr., Palmrose, Z. V. \& Scholz, S. (2004), 'Auditor independence, non-audit services, and restatements: was the US government right?' Joumal of Accounting Research, Vol. 42, No. 3, pp. 561-88.

Klein, A. (2003), 'Likely effects of stock exchange governance proposals and Sarbanes-Oxley on corporate boards and financial reporting', Accounting Horizons, Vol. 17, No. 4, pp. 343-55.

'Lay may testify' (2002), CNN Money, 8 February, pp. 1-3.

Marden, R. E., Edwards, R. K. \& Stout, W. D. (2003), 'The $\mathrm{CEO} / \mathrm{CFO}$ certification requirement', $C P A$ Journal, Vol. 73 , No. 7, pp. 36-42.

McConnell, D. K., Jr. \& Banks, G. Y. (2003), 'How Sarbanes-Oxley will change the audit process', Joumal of Accountancy, Vol. 196, No. 3, pp. 49-55.

Nagy, A. L. \& Cenker, W. J. (2007), 'Internal audit professionalism and Section 404 compliance: the view of chief audit executives from northeast Ohio', International Joumal of Auditing, Vol. 11, No. 1, pp. $41-49$.

Rezaee, Z. (2005), 'Causes, consequences, and deterrence of financial statement fraud', Critical Perspectives on Accounting, Vol. 16, No. 3, pp. 277-98.

Ribstein, L. E. (2002), 'Market vs. regulatory responses to corporate fraud: a critique of the Sarbanes-Oxley Act of 2002', Joumal of Corporation Law, Vol. 28, No. 1 , pp. $1-67$

Romano, R. (2005), 'The Sarbanes-Oxley Act and the making of quack corporate governance', The Yale Law Journal, Vol. 114, No. 7, pp. 1524-611.

Ronen, J. \& Berman, A. (2004), 'Musing on post-Enron reforms', Joumal of Accounting, Auditing $\mathcal{E}$ Finance, Vol. 19, No. 3, pp. $331-42$.

Sarbanes-Oxley Act of 2002, One Hundred Seventh Congress, Second Sess. 74 (2002).

'Sarbanes-Oxley on trial' (2009), The Wall Street Joumal, 4 December, p. A24

Scannell, K. (2007), Moving the market: costs fall again for firms to comply with Sarbanes', The Wall Street Journal, 16 May, p. 3.

Triola, M. F. (2007), Elementary Statistics Using Excel, 3rd edn, Upper Saddle River, NJ: Pearson Education.

Tsui, A. S. (1989), 'An empirical examination of the multiple constituency model of organizational effectiveness', Best Papers Proceedings of the Academy of Management, Washington, DC, pp. 188-192.

Tsui, A. S. (1990), 'A multiple-constituency model of effectiveness: an empirical examination at the human resource subunit level', Administrative Science Quarterly, Vol. 35, No. 3, pp. 458-84.

Vogt, W. P. (1993), Dictionary of Statistics and Methodology, Thousand Oaks, CA: Sage Publications.

Wilcox, K. (2007), 'Dealing with Sarbox', The Wall Street Journal, 1 June, p. 13. 